\title{
ANALISIS KEPEMIMPINAN NON MUSLIM MENURUT FIQIH DAN HUKUM TATA NEGARA DI INDONESIA
}

\author{
Siti Qoniah \\ Institut Agama Islam Negeri (IAIN) Kudus \\ Jalan Conge Ngembal Rejo, Kudus, Jawa Tengah \\ Pos-el: Qoniah962@gmail.com \\ Ashif Az Zafi \\ Institut Agama Islam Negeri (IAIN) Kudus \\ Jalan Conge Ngembal Rejo, Kudus, Jawa Tengah \\ Pos-el: Ashifazzafi@iainkudus.ac.id
}

\begin{abstract}
The leader is the most important figure in a sphere of community life, both small and broad, the progress of a sphere of society depends on how the leader in bringing the country, whether it is more advanced, prosperous or vice versa. Therefore, it is the responsibility of all of us as a citizen to be selective in choosing a leader. Islam as a religion of revelation for Muslims and make it as a guide in carrying out their lives, including in political matters, namely becoming a leader. The leader has an important position in Islam. In the Islamic view of non-Muslim leaders there are differences of opinion of the scholars about the legitimate or non-Islamic leaders in the Islamic perspective. The difference in opinion is due to the perception in understanding the verses about saints or awliya 'mentioned in the Qur'an Moreover, the current reality of the state of Indonesia is not an Islamic state, but a democratic state, which has a majority of its citizens, who are Muslim. In Indonesia, to become a leader in positive law and in the Constitution there is no explanation which explains that the requirements to be a leader in Indonesia must be religious and prohibit non-Muslim religion. the opening of the 1945 Constitution only explained that in Indonesia there was no difference between ethnicity, religion, language, culture, etc. Therefore, it is necessary to conduct a deeper study in understanding it so that there is no misunderstanding among the people.
\end{abstract}

Keywords: Leaders; Indonesia; Islam; Non-Muslims; Constitution

Abstrak: Pemimpin merupakan sosok yang paling penting dalam sebuah ruang lingkup dikehidupan masyarakat, baik lingkup kecil maupun luas, kemajuan suatu lingkup masyarakat tergantung bagaimana pemimpin itu dalam membawa negara tersebut, entah itu semakin maju, makmur atau sebaliknya . Oleh karena itu, sudah tanggung jawab kita semua sebagai warga suatu untuk selektif dalam memilih seorang pemimpin. Islam sebagai agama wahyu bagi umat Islam dan menjadikannya sebagai pedoman dalam menjalankan kehidupannya, termasuk dalam hal politik yaitu menjadi seorang pemimpin. Pemimpin memiliki posisi penting dalam Islam. Dalam pandangan islam pemimpin nonmuslim terdapat berbagai macam pendapat ulama tentang "sah atau tidaknya pemimpin nonIslam dalam prespektif agama Islam". Perbincangan tersebut ada karena presepsi pada pemahaman ayat-ayat tentang "wali atau awliya" yang terdapat dalaam Al-Qur'an. Apalagi dengan adanya realitas saat ini negara Indonesia bukanlah negara Islam, melainkan negara demokrasai yang mayoritas warganya adalah seorang muslim. Di negara Indonesia,ketentuan dalam hukum-hukumnya yaitu UUD 1945 tidak yang menyebutkan bahwa syarat untuk menjadi seorang pemimpin di Indonesia haruslah warga negara yang beragaama Islam dan melarang non muslimuntuk mencalonkan dirinya menjadi seorang pemimpin yang mayoritas penduduknya beragama Islam .Tidak ada satupun UUD dan pasal yang disana berisi "larangan bagi seorang non muslim untuk menjadi pemimpin di Indonesia". Pada pembukaan UUD 1945 hanya menjelskan baahwa di negara Indonesia terdapat berbagai macam suku, agama,bahasa,budaya,dan lain-lain. Maka dari itu, perlu adanya penelitian yang lebih lanjut lagi dalam memahami hal itu agar tidak terjadi kesalafahaman diantara masyarakat.

Kata kunci: Pemimpin; Indonesia; Islam; Non muslim; UUD

AL-IMARAH: Jurnal Pemerintahan dan Politik Islam 


\section{Pendahuluan}

Pendirian suatu negara menurut pemahaman yang ada pada sumber-sumber Agama Islam tidak ada ayat yang mewajibkan atau memerintahkaannya. Sebuah negara Islam adalah negara yang didalamnya terdapat kedaulatan Islam, dimana pemerintah ingin membangun hubungan kemasyarakatan yang Islami pada kaidah dan nilai-nilai Islam. Termasuk dalam hal politik yaitu hukum tata negara dalam pemilihan pemimpin negara. Islam dan politik merupakan gabungan yang selalu menjadi perbincangan dalam khazanah keislaman. Salah satu permasalahan yang sering diperbincangkan yaitu "kepemimpinan non muslim". Perbincangan tentang permasalahan ini selanjutnnya mengarah pada hubungan antara agama dan negara. Maka, ketika suatu daerah melaksanakan pilpres, pilgub, atau pilkades terdapat calon pemimpin dari kalangan minoritas mencalonkan diri, masalah tentang "kepemimpinan non muslim" kembali menjadi perdebatan.

Manusia memiliki kewenangn dalam bidang politik, paling penting yang bersifat struktural dan prosedural yang berkaitan dengan kekreativannya. Konsep persamaaan dalam Islam adalah didasarkan pada sesama manusia didalam kehidupannya, didalam hak dan kewajibannya dihadapan UU,dihadapan Allah, di dunia dan diakhirat,persamaan tersebut juga berlaku pada kalangan minoritas. Pemerintah seharusnya dalam menjalankan pemerintahan dengan ketertiban, kepastian hukum, dan seorang pemimpin bertanggungjawaab terhadap semua tugas-tugasnya sebagai aparatur pemerintah. Mengabdikan dirinya untuk kepentingaan bangsa dan mengusahakan kemakmuran rakyat. Istilah pemimpin dalam Islam ada empat yaitu khalifah, imam, ulu al-amr, awliya'.

Warga negara Indonesia kebanyakan Islam. Banyak para ulama yang berpandapat bahwa umat Islam dilarang untuk memilih kalangan minoritas sebagai pemimpin, sesuai dengan surat An-nisa 138139, Firman Allah SWT:

"katakanlah kepada orang-orang munafik bahwa mereka akan mendapat siksaaan yaang pedih (yaitu) orang orang yang mengambil orang-orang kafir menjadi teman-teman penolong dengan meninggalkan orang-orang mukmin. Apakah mereka mencaari kekuataan disisi oraang kafir itu? Maaka sesungguhnyaa semиa kekuaatan kepunyaan Allah". 
AL-IMARAH: Jurnal Pemerintahan dan Politik Islam Vol. 5, No. 2, 2020

An-Nisa 144,Firman Allah SWT :

"Hai orang-oraang beriman, janganlah engkau mengambil oraang-orang kafir menjadi waali dengan meninggalkan orang orang mukmin. Inginkah kamu mengadaakan alasaan yaang nyata baagi Allah (untuk menyiksaamu)".

Hubungan politik muslim dan non muslim terdapat pada surah Al-Maidah ayat 51, Firman Allah SWT :

"Hai orang-orang beriman janganlah kaтu mengambil orang-orang yahudi dan nasroni menjadi pemimpinpemimpinmu sebagiaan mereka adalah pemimpin bagi sebagian yang lain. Barang siapa diantara kaтu mengambil mereka menjadi pemimpin, maka sesungguhnya orang itu termaasuk bagiaan mereka. Sesungguhnya Allah tidak memberi petunjuk bagi oraang-orang yang dzolim".

Hukum diberikan pada semua warga negara memiliki. Akan tetapi, untuk memegang kekuasaan lebih diutamakan warga negara yang muslim, karena dalam penerapan hukum Islam yang meyakini adanya hukum Islam hanyalah orang muslim saja, dan yang non muslim hanya menerapkannya dalam kehidupan bernegara ini. Menjadikan seseorang yang adil sebagai pemagang kekuasaan dalam negara itu harus, agar keadilan dan kebenaran dapat terwujud dalam kelompok tersebut. Maka dari itu ketentuan yang harus terpenuhi untuk menjadi seorang pemimpim adalah adil yang terlihat dalam keimanan dan komitmennya dalam memimpin suatu kelompok.

Seorang warga yang non muslim apabila dijadikan pemimpin di negara yang maayoritasnya muslim seperti Indonesia, apabila dilihat dari "hak asasi manusia (HAM)" jadi tidak masalah apabila seorang dari kalangan minoritas ingin menjadi sebagai seorang kepala negara karena dia juga mempunyai hak sama untuk mencalonkaan diri menjadi seorang pemimpin dan juga hak untuk dipilih menjadi seorang pemimpin. Agama memberikan warga negara hak untuk menjadi seorang pemimpin karena pemimpin merupakan tanggungjawab yang diberikan khusus untuk seseorang yang dinilai mempunyai keahlian, bertanggungjawaab,memiliki sikap jujur, adil, dan tentunya dapat membangun Indonesia lebih maju. Konsepsi kepemimpinan pemerintahan yang dimaksud dalam pemimpin disini adalah pemimpin pada tiga cabang pemerintahan, diantaranya eksekutif, legeslatif, dan yudikatif. Pada cabang eksekutif 
kepemimpinan dipegang oleh pemimpin pemerintah mulai dari tingkat terendah sampai tingkat tertinggi yaitu lurah/kepala desa, camat, bupati/walikota, gubernur, dan presiden.

Ditelaah lebih jauh dalam konsep kepemimpinan akan sangat luas, karena dalam kepemimpinan disebuah negara tidak sedikit pembahasannya, penulis dalam hal ini akan membahaas kepemimpinan dalam suatu pemerintah, kalangan manapun bisa menjadi seorang pemimpin, apabila ia mampu melaksanakannya. Seseorang bisa menjadi kepala negara berdasarkan keputusan umat Islam sendiri baik dengan pemilu maupun penunjukan.

\section{Pembahasan}

Kepemimpinan adalah keterampilan ,kemapuan,dan perilaku yang dilakukan oleh seseorang untuk memberikan pengaruh kepada orang lain atau kelompok manusia pada wadah yang terkoordinasi, dengan langkah yang baik untuk menggapai satu atau lebih tujuan yang telah direncanakan. Seseorang yang menjadi pemimpin memberikan pengaruh terhadap tingkah laku sosial masyarakat, dengan cara mengatur, mengarahkan, memotivasi usaha dan tindakan yang dilakukaan setiap orang atau kelompok dalam suatu organisasi. ${ }^{1}$

Kepemimpinan dalam Islam merupakan perwujudan iman dan amal sholih berupa interaksi, dan tindakan mengkoordinasi dan mengarahkan baik secara vertikal maupun secara horizontal dengan jalan menyeru kepada amal ma'ruf naahi munkar.Kepemimpinan dalam dalam ajaran Islam didefinisikan sebagai tugas yang dipercayakan (amanah) dari Allah SWT yang penanggungjwabnya bukaan hanya kepadaa pengikut atau anggotanya ,namun juga dipertaanggungjawabkan kepada Allah SWT .

Seorang pemimpin dalam Islam ada dua definisi. (1) berarti amara yang sering disebut dengan ulil amri. Dalam Al-Qur'an ayat (4-5) '"Hai orang-orang beriman ,taatilah Allah dan Rasul-Nya,dan ulilamri diantara kamu'. Pada firman Allah ini diketahui bahwa amara merupakan orang yang mendapat tanggungjawab untuk mengayomi rakyat. Jika ia tidak menjalankan amanah tersebut berarti dia bukan pemimpin sebenarnya. (2) yaitu khadimul ummah (pelayaan umat) sebaagi seoarang kepala negara harus bisa

\footnotetext{
${ }^{1}$ Indah Kumala Dewi, Ali Mashar."NilaiNilai Profetik dalam Kepemimpinan Modern pada Manajemen Kinerja". (Jogjakarta:CV. Gre Publishing, 2019), hal. 13
} 
AL-IMARAH: Jurnal Pemerintahan dan Politik Islam Vol. 5, No. 2, 2020

menempatkan dirinya untuk mengayomi dan melayani apa-apa yang dibutuhkan warga negaranya asalkan itu sesuai dengan hukum dan syariat. $^{2}$

Mujar Ibnu Syarif menyatakan bahwa pengangkatan pemimpin merupakan suatu perkara yang penting, tidak mungkin dalam suatu negara tidak ada pemimpin yang melindungi dan mengatur negara tersebut. Ibnu Taimiyah berkata'’empat puluh tahun negara yaang dipimpin oleh orang dzolim lebih baik dari pada negara yaang satu malam saja tapi tanpa pemimpin". Indonesia sudah melakukan hal penting tersebut karena semenjak negara Indonesia merdeka yaitu pada tanggal 17 Agustus 1945, kemudian besoknya BPUPKI bersidang untuk menentukan pemimpin Indonesia yang pada saat itu disetujui presidennya Ir. Soekarno dan Wakilnya yaitu Drs. Moh. Hatta. ${ }^{3}$

Syarat-syarat seorang yang ingin mencalonkan diri menjadi seorang pemimpin antara lain :

1) Adil

2) Berpengetahuan luas yang dapat menyelasaikan berbagai masalah

${ }^{2}$ Muhammad Harfin Zuhdi. 2014."Konsep Kepemimpinan dalam Perspektif Islam". (Institut Agama Islam Negeri Mataram).

${ }^{3}$ Muhammad Jufri, Ahmad Dahlan."Kepemimpinan Non Muslim Di Indonesia Perspektif Hukum Islam", 2018
3) Pancaindra yang lengkap

4) Sehat dan tidak memiliki cacat pada anggota tubuhnya yang bisa mempengaruhi tanggungjawabnya sebai seorang pemimpin.

5) Mempunyai ide dan gagasan untuk memimpin rakyat dan mengurusi berbagai urusan rakyatnya.

6) Berani melindungi nagara dan melawan musuh.

7) Seorang warga negara tersebut. ${ }^{4}$

Cara Pengangkatan Kepalaa Negara Seseorang dapat menempati posisi kepala negara dengan tiga cara:

1. Dipilih langsung oleh rakyat.

2. Dipilih oleh Dewan Perwakilan.

Pemilihan kepala negara oleh kalangan Dewan Perwakilan menjadi perdebatan para ulama dulu dari berbagai madzhab yaitu berapa jumlah dewan pemilih yang memilih kepala negara supaya sah dalam menempati jabatannya. Ada kelompok yang mengungkapkan bahwa seorang kepala negara sah dalam menempati jabatannya apabila mayoritas dewan pemilih

\footnotetext{
${ }^{4}$ Al-Mawardi. "Hukum Tata Negara dan Kepemimpinan dalam Takaran Islam". (Jakarta: Gema Insani Press, 2000). Hal.17
} 
ikut serta dalam memilihnya yang menyebabkaan kepemimpinannya diterima dengan baik dan dengan hati yang ikhlas.

Sementara itu kelompok yang lain mengungkapkan bahwa jumlah minimal yang dapat membuat pemimpin tersebut sah dalam menempati jabatannya yaitu lima orang yang sepakat untuk mengangkat orang tersebut sebagai pemegang jabatan itu atau satu orang mencalonkan seseorang dan kemudian disetujui oleh empat orang lainnya.

Prinsip-prinsip bernegara menurut hukum fiqih:

1) Prinsip Keadilan

Prinsip keadilan terdapat dalam firman Allah surah Al-An'am ayat $160 .^{5}$

"Barang siapa membawa amal baik, maka baginya pahala sepuluh kali lipat amalnya, dan barangsiapa yang membawa perbuatan jahat maka dia tidak diberi pembalasan melainkan seimbang dengan kejahatannya, sedang mereka sedikitpun tidak dianiaya (dirugikan)”.

2) Prinsip Kekuasaan sebagai Amanah

${ }^{5}$ Djazuli, Op.Cit.hal.32
Kekuasaan adalah amanah,amanah ibarat janji dalam bentuk tanggungjawab. Maka dari itu, amanat harus benar-benar disampaikan pada orang yang berhak menerima amanah tersebut. Amanah itu harus dipelihara dan dijalankan atau ditarapkan dengan sebaik-baiknya sesuai dengan syariat. ${ }^{6}$

Amanah terdapat dalam Al-Qur'an surah An-Nisa ayat 58

"Sesungguhnya Allah menyuruh kamu menyampaikan amanat kepadaa yang berhak menerimanya, dan menyuruh kamu apabila menetapkan hukum diantara manusia supaya kamu menetapkan dengan adil. Sesungguhnya Allah memberikan pengajaran yang sebaik-baiknya kepadaamu. Sesungguhnya Allah adalah Maha Mendengar dan Maha Melihat".

3) Prinsip Musyawarah

Dalam Al-Qur'an prinsip ini terdapat dalam surat al-Imran ayat 159

"Maka disebabkan rahmat dari Allah-lah kamu berlaku

\footnotetext{
${ }^{6}$ Muhammad Tahir Azhari, Op.Cit, hal.107
} 
AL-IMARAH: Jurnal Pemerintahan dan Politik Islam Vol. 5, No. 2, 2020

lemah lembut terhadap mereka.

Sekiranya kamu bersikap keras

lagi berhati kasar, tentulah mereka menjauhkan diri dari sekelilingmu,karena itu ma'aafkanlah

mereka,mohonkanlah ampum bagi mereka, dan bermusyawarahlah dengan mereka dalam urusan itu. Kemudian apabila kamu telah membulatkan tekad,maka bertawakkallah kepada Allah. Sesungguhnya Allah menyukai orang-orang yang bertawakkal kepada Allah SWT". ${ }^{7}$

Allah memerintahkan manusia untuk menjadikan musyawarah sebagai salah satu unsur dari beberapa unsur dasar dalam negara Islam. Musyawarah merupakan hak keikutsertaan rakyat dalam menangani kasuskasus hukum masyarakat. ${ }^{8}$

4) Prinsip persamaan Prinsip persamaaan dalam Islam terdapat dalam al-Qur'an, surah al-Hujurat ayat 13

"Hai manusia,sesungguhnya kami menciptakan kamu dari seorang laki-laki dan perempuan dan menjadikan kamu berbangsabangsa dan bersuku-suku supaya kaти salin kenal-mengenal. Sesungguhnya orang yang paling mulia diantara kamu disisi Allah ialah orang yang paling diantara kamu. Sesungguhnya Allah Maha Mengetahui lagi Maha Mengenal". 9

5) Prnsip Pengakuan dan Perlindungan terhadap Hak Asasi Manusia Prinsip ini tercantum dalam Al-Qur'an dalam surah AlIsra ayat 70

"Dan sesungguhnya telah kami muliakan anak-anak Adam, Kami angkat mereka di daratan dan di lautan, Kami beri mereka rezeki dari yang baik-baik dan Kami lebihkan mereka dengan kelebihan yang sempurna atas kebanyakan makhluk yang telah Kami ciptakan".

6) Prinsip Kesejahteraan

Dalam Islam prinsip ini diwujudkan melalui pentingnya zakat dalam Negara. Hal ini

\footnotetext{
${ }^{77}$ Departemen Agama RI “Al-Qur'an dan Terjemah 30 juz".hal. 90.

${ }^{8}$ Muhammad Tahir Azhari. Op.Cit.,hal. 114
}

9 Departeman Agama RI 'Al-Qur'an dan Terjemah 30 juz". Hal. 726. 
terdapat dalam Al-Qur'an surah

at-Taubah ayat 103

"Ambillah zakat dari

sebagian harta mereka, dengan

zakat itu kamu membersihkan dan

mensucikan mereka dan

mendoalah untuk mereka.

Sesungguhnya doa kamu itu

menjadi ketenteraman jiwa bagi

mereka. Dan Allah Maha

Mendengar lagi Maha

Mengetahui"

7) Prinsip Ketaatan Rakyat

Prinsip ini sesuai dengan Al-

Qur'an surah an-Nisa ayat 59

"Hai orang-orang yang beriman, taatilah Allah dan taatilah Rasul(Nya),dan ulil amri diantara kamu . Kemudian jika kamu berlainan pendapat tentaang sesuatu, maka kembalikanlah ia kepadaa Allah (Al-Qur'an) dan Rasul (Sunnahnya), jika kamu benarbenar beriman kepada Allah dan hari kemudian. Yang demikian itu lebih utama (bagimu) dan lebih baik akibatnya". ${ }^{10}$

8) Prinsip Perdamaian

10 Departeman Agama RI "Al-Qur'an dan Terjemah 30 juz”. Hal. 114.
Prinsip perdamaian tertera dalam surah Al-Baqarah ayat 208

"Wahai orang-orang yang beriman, masuklah kamu kedalam Islam keseluruhan, daan janganlah kamu turuti langkahlangkah syaitan. Sesungguhnya syaitan itu musuh yang nyata bagimu”.

9) Peradilan Bebas

Hal ini menunjukkan bahwa setiap keputusan yang diambil harus bebas dari pengaruh siapapun dan juga memperhatikan prinsip amanah yang tercantum dalam firman Allah Al-Qur'an surah An-Nisa ayat 58

"Sesungguhnya Allah menyuruh kamu menyampaikan amanat kepada yang berhak menerimanya, dan menyuruh kamu apabila menetapkan hukum diantara manusia supaya kamu menetapkan dengan adil. Sesungguhnya Allah memberikan pengajaran yang sebaik-baiknya kepadamu. Sesungguhnya Allah adalah Maha Mendengar lagi Maha Melihat”. 
AL-IMARAH: Jurnal Pemerintahan dan Politik Islam Vol. 5, No. 2, 2020

\section{Kepemimpinan Non Muslim Menurut} Fiqih

Suatu negara kebangsaan menggolongkan warga negara nya menjadi kelompok-kelompok rakyat sesuai dengan bangsa asal atau ras yang membentuk negara tersebut atau yang mendominasinya, serta yang bertanggungjawab atas penyelenggaranya. Disinilah berlaku istilah "mayoritas" dan "minoritas" bagi masing-masing kelompok tersebut. Tugas menuntun dan membuat kebijaksanaan dalam suatu negara kebangsaan selalau berada ditangan kaum mayoritas. Untuk kaum minoritas dengan kebangsaan yang sama, mereka tidak akan dipercayai atau dianggap mampu memikul tanggungjawab ini. Kedudukan ini tidaklah secara terang-tarangan dinyatakan atau bahkan diakui. Mungkin Undang-Undang Dasar tersebut secara tegas menghapus semua deskriminasi diantara para warga negaranya, tetapi justru deskriminasi inilah yang pada prakteknya tumbuh subur disetiap negara kebangsaan. Sekalipun anggota kelompok minoritas dipercayai jabatan penting, tetapihal ini biasanya merupakan hasi tawar-menawar yang sifatnya perseorangan. Dalam kenyataannya, dimanapun kelompok minoritas tidak memiliki tempat dalam masalah-masalah negara. ${ }^{11}$

Kaum minoritas memiliki hak-hak yang harus didapat dari suatu nagara, karena hak-hak ini ada didalam syariah Islam, kaum mayoritas tidak boleh mengambil hak-hak yang dimiliki kaum minoritas. Namun mereka diperbolehkan jika ingin memberikan hak-hak lain atau hak-hak istimewa kepada kaum minoritas asalkan hak yang diberikan tersebut sesuai dengan perintah syariah. Hak-hak tersebut diantaranya:

1. Perwakilan politik;

2. Kebebasan mengemukakan pendapat;

3. Pendidikan;

4. Jabatan Pemerintahan;

5. Perdagangan dan Profesi ${ }^{12}$.

Bijaksana, merakyat, berpendidikan merupakan kriteria pemimpin yang diinginkan oleh suatu negara,dan juga memiliki kepercayaan sama dengan masyarakat supaya tidak terjadi kesalahpahaman serta tidak adanya

${ }^{11}$ Abul A'la Al Maududi. "Hukum Dan Konstitusi Sistem Polotik Islam", (Bandung:Mizan, 1990), hal. 298

${ }^{12}$ Abul A'la Al Maududi. "Hukum Dan Konstitusi Sistem Polotik Islam", (Bandung:Mizan, 1990), hal. 318 
perbedaan kepercayaan antara rakyat dengan pemimpin. Hukum yang berkaitan dengan pengangkatan pemimpin non muslim senantiasa menjadi perbincangan dikalangan masyarakat dan para ahli dari dulu hingga sekarang.

Menjadikan kaum minoritas sebagai penguasa itu dilarang, hukum menegaskan kaum minoritas apabila mengurusi urusan umat muslim itu haram, dalam pembahasan ini yang berkaitan dengan pemimpin yang berasal dari kaum minoritas terdapat beberapa pendapat dari beberapa ulama tafsir yaitu

a) Syaikh Imam Qurtubi

"pemimpin harus dipegang oleh umat muslim dan bahaya jika jabatan pemimpin dipercayakan padaa seorang non muslim. Beliau mengatakan pada masa sekarang ini keadaan sudah terbalik dan berubah sedemikian rupa, hingga umat muslim mempercayakan semuanya pada orang kafir, dan keadaan umat muslim sekarang ini semakin terpuruk". 13

${ }^{13}$ Syeikh Imam Qurtubi, Tafsir al-Qurtubi, Ter. Dudi Rosyadi, et. Al,Pustaka Azzam, Jakarta, Jilid. IV, 2008, hal. 446. b) Ibnu Katsir

$$
\text { "Riwayat dari Khalifah Umar }
$$

ditambah ayat diatas adalah dalil bahwa orang kafir dzimmi tidak boleh dikerjakan sebagai juru tulis sehingga merasa lebih tinggi dari kaum muslum daan mengetahui rahasia-rahasia umt muslim sehingga dikhawatirkan akan disampaikan pada musuh, orang kafir harbi". ${ }^{14}$

c) Al-Qadhi Iyadh

$$
\text { "para ulama bersepakat }
$$

bahwa kepemimpin Islam tidak sah diberikan pada orang kafir, dan bahkan bila pemimpinnya muslim kemudian dia keluar dari Islam maka dia harus turun dari jabatan tersebut" $" 15$.

d) Ibnu Mundzir

"Seluruh ahli ilmu bersepakat bahwa orang kafir sama sekali tidak boleh menjadi pemimpin bagi kaum muslimin dalam keadaan apapun". 16

e) Hasbias Siddiqi

"mengatakan kerja sama bantu-membantu, dan bersahabat

${ }^{14}$ Tafsirul Al-Qur'an Adzim, Jilid.I, H.398

${ }^{15}$ Shahih Muslim bi Syarh Al-Nawawi, Jilid. XII, hal. 229.

${ }^{16}$ Ahkam Ahl Al-Dzimmah li Ibn Qayyim Al-Jauziyyah, Jilid. II, hal. 414. 
AL-IMARAH: Jurnal Pemerintahan dan Politik Islam Vol. 5, No. 2, 2020

setia diantara dua orang yang berlainan agama untuk kemaslahatan dunia tidak dilarang. Yang dilarang adalah jika kita bersahabat setia dengan Yahudi dan Nasrani dalam hal-hal yang dapat merusak atau bertentangan dengan kemaslahatan para mukmin seperti yang diungkapkan beliau dalam tafsir al-qur'an ulmajid an-nur, Tuhan hanya melarang kamu bersahabat dengan orang-orang yang terang-terangan memusuhimu,yang memerangimu, yang mengusirmu atau membantu orang-orang yang mengusirmu seperti yang dilakukan orang musyrik mekah".

f) Sayyid Qutbdi

$$
\begin{aligned}
& \text { "agama Islam menyuruh } \\
& \text { pemeluknya agar melakaukan } \\
& \text { toleransi dan melakukan pertemanan } \\
& \text { yang baik dengan dengan ahli kitab. } \\
& \text { Terkhusus bagi mereka yang } \\
& \text { mengatakan sesungguhnya kami } \\
& \text { adalah orang-orang Nasrani, akan } \\
& \text { tetapi al-qur'an melarang mereka } \\
& \text { memberikan loyalitas dan kesetiaan } \\
& \text { kepada mereka semua. Karena } \\
& \text { toleransi dan bergaul dengan baik } \\
& \text { itu adalah masalah akhlak, dan }
\end{aligned}
$$

perilaku, sedangkan masalah wala' berarti pertolongan atau bantumembantu antara satu golongan dengan saatu golongan lain. Sedangkan hal ini tidak ada tolongmenolong antaraa kaum mayoritas dengan kaum minoritas".

g) Ahmad Musthafa Al-Maraghi "pengangkatan pejabat non muslim tidak ada masalah, memang banyak ayat Al-Qur'an yang secara tegas melarang kaum muslimin untuk mengangkat kaum non muslim menjadi walinya, namun ada alasan mengapa hal itu dilarang,secara umummerupakan pelanggaran mengambil non muslim sebagai teman dalam suatu hal yang membahayakan kaum mayoritas (muslim), seperti membuka rahasiarahasia khusus yang berkaitan dengan urusan agama,bersekongkol untuk memerangi kaum muslim lainnya". 17

Ibnu Taimiyah berkata "pemimpin yang mampu melaksanakan keadilan meskipun non muslim lebih baik dari pada pemimpin yang beragama Islam tetapi tidak

\footnotetext{
${ }^{17}$ Jurnal oleh Husnaeni, "Kajian Hukum Islam terhadap Kepemimpinan Non Muslim di NKRI “ Institut Agama Islam Negeri Bone
} 
maтри melaksanakan keadilan. Negara yang adil itu disokong oleh Allah SWT meskipun negara itu dipimpin oleh seorang yang bukan non muslim dan negara yang despotik tidak disokong Allah SWT meskipun pemimpinnya seorang muslim, ia menegaskan bahwa syarat seorang pemimpin itu adalah adil tanpa memperhatikan agama yang dianutnya".

Dalam suatu kepemimpinan semua warga negara memiliki hak masing-maasing, maka dari itu setiap warga negara memiliki hak untuk dipilih menjadi pemimpin dan juga untuk memilih seseorang untuk menjadi pemimpin negaranya. Ketidaksamaan identitas latar belakang yang dimiliki setiap warga negara (keagamaan, etnis, gender, strata sosial) tidak boleh menjadi pembatas atas persamaan hak-hak yang didapat setiap warga negara. Kehadiran seorang pemimpin yang berasal dari kalangan kaum non muslim diakui oleh Islam. Oleh karena itu, sangat ada kemungkinan memilih pemimpin non muslim dikalangan masyarakaat muslim yang terpenting tidak mengancam kebebasaan beragama, dalam suatu masyarakat dimana antara kaum minoriras dan kaum mayoritas bersatu dalam suatu negara maka keduanya bisa merajut hubungan harmonis yang saling memerlukan. ${ }^{18}$

Munawir Sajdali secara tidak langsung yang terdapat dalam tulisannya tidak berpendapat bahwa "seorang pemimpin dari golongan minoritas boleh untuk memimpin kalangan mayoritas, namun secara garis besar menegaskan bahwa dalam sistem politik maupun sistem hukum ada kesamaan antara Pancasila dengan prinsip-prinsip dan tata nilai yang telah ada dalam Al-Qur'an, karena Indonesia menggunakan prinsip keadilan dalam hal mencari seorang pemimpin,bahwasannya kebanyakan warga negara Indonesia adalah muslim dan selebihnya adalah kalangan minoritas yaitu non muslim,kalangan minoritas mendapatkan hak yang sama dengan kaum muslim yaitu haak untuk memilih dan dipilih menjadi seorang pemimpin, karena negara Indonesia adalah negara yang berdasarkan pancasila dengan Ketuhanan Yang Maha Esa ,sebagai sila pertama, karena pendiri Negara Republik Indonesia telah merumuskan Pancasila sebagai ideologi negara Indonesia".

Memilih kepala pemerintahan dari kalangan minoritas seperti presiden

\footnotetext{
${ }^{18}$ Amanda Rahmat Hidayat."Kepemimpinan Non Muslim menurut Fiqih Siyasah dan Hukum Tata Negara Indonesia", (Lampung: Skripsi, 2013), hal. 47-48.
} 
AL-IMARAH: Jurnal Pemerintahan dan Politik Islam Vol. 5, No. 2, 2020

hukumnya haram, itu seperti halnya menjadikan kaum mayoritas berada dibawah kekuasaan kaum minoritas. Memilih pemimpin dari kalangan minoritas apabila tidak memenuhi sayarat atau calon pemimpinnya memenuhi syarat tapi tidak memilih juga haram. Orang Islam tidak boleh menyerahkan urusan pemerintahan kepada orang non muslim kecuali memang dalam keadaan yang penting dan hal itu membawa manfaat untuk negara yang membawa kemajuan yang lebih baik. Urusan kenegaraan tidak boleh diserahkan kepada orang kafir begitu juga ketika ada pemimpin muslim akan tetapi melakukan kekufuran, maka dia harus dilengserkan dari jabatannya sebagai kepala pemerintahan.

Kekufuran merupakan alasan seorang pemimpin dilengserkan dari jabatannya, bahkan menurut para ulama melengserkan pemimpin tersebut merupakan hal yang wajib. Barangsiapa yang melakukan hal demekian maka akan memperoleh pahala dan barangsiapa bermain-main dengan hal itu mendapatkan dosa. Maka dari itu, kepala pemerintahan seharusnya dalam memimpin negaranya harus mempunyai visi dan misi yang tersruktur, dan juga harus membentengi diri agar tidak melakukan hal-hal yang justru 
mereka sebagai kawan, Maka mereka itulah orang-orang yang zalim "(ayat 9). ${ }^{19}$

Dari ayat tersebut, dapat diketahui bahwa yang sebelumnya kaum non muslim sangat memusuhi kaum muslim sekarang dapat bersatu dan berhubungan secara harmonis. Hal itu merupakan sesuatu yang didambakan, sedangkan dalam ayat selanjutnya surah Al-Muntahanah diketahui bahwa Allah SWT tidak melarang kaum muslim melakukan hal baik dan bersifat adil kepada kaum non muslim yang tidak mengancam keselamatan kaum muslim.

Dalam pembahasan ini dapat dijadikan sebagai pengetahuan dan ilmu dalam menjalankan pemerintahan. Indonesia merupakan negara yang mempunyai beberapa agama didalamnya. Akan tetapi, mayoritas penduduknya beragama Islam, yang tentunya mereka ingin pemimpin mereka seorang dapat menunjukkan bahwa Islam sebagai kepercayaan yang bisa mengayomi beberapa kepercayaan yang lain 'dan juga dapat menyatukan perbedaan yang ada menjadi satu yang tentunya juga dapat mensejahterakan membawa kemajuan untuk Negara Kesatuan Republik Indonesia.

Kepemimpinan menurut hukum fiqih dan Al-Qur'an sebagai landasan dan juga

\footnotetext{
${ }^{19}$ Departeman Agama RI Al-Qur'an dan Terjemah 30 juz. Hal. 802-803.
}

beberapa cara dalam memahaminya yaitu: “(1) ijma'(2) qiyas (3) mashalah mursalah (4) saad al-dzariah dan fath al- dzari'ah (5) al-adalah (6) istihsan dan kaidah-kaidah fiqhiyyah dan yang menjadi hal terpenting dari aturan itu sendiri yaitu Al-Qur'an”. ${ }^{20}$ Beberapa ahli tafsir menganggap menjadikan non muslim sebagai pemimpin adalah haram dan itu sudah ada sejak dulu seperti dalam "tafsir Syaikh Imam Qurtubi, Ibnu Katsir, Al-Qadhi Iyadh, Ibnu Mundzir, dan Ibnu Hajar". Para ahli tafsir menyatakan bahwasanya dengan menjadikan non muslim sebagai seorang pemimpin adalah haram. Akan tetapi, menurut Ibnu Taimiyah "seorang pemimpin yang mampu mewujudkan/melaksanakan keadilan meskipun ia seorang non muslim apabila ia memang lebih baik dari pada seorang pemimpin muslim tapi ia tidak dapat mewujudkan keadilan maka ia yang lebih layak untuk menjadi pemimpin”.

Syarat bolehnya seorang non muslim menjadi pemimpin yakni mereka tidak termasuk dalam golongan non muslim yang munafiq mengacu pada firman Allah SWT :

\footnotetext{
${ }^{20}$ Amanda Rahmat Hidayat."Kepemimpinan Non Muslim menurut Fiqih Siyasah dan Hukum Tata Negara Indonesia", (Lampung: Skripsi, 2013), hal. 70-71
} 
AL-IMARAH: Jurnal Pemerintahan dan Politik Islam Vol. 5, No. 2, 2020

"kecuali orang-orang mushrikin yang kamu telah mengadakan perjanjian dengan mereka dan mereka tidak mengurangi sesuatupun dari isi perjanjian mu dan tidak pula mereka membantu seseorang yang memusuhi kamu, maka terhadaap mereka itu penuhilah janjinya sampai batas waktunya. Sesungguhnya Allah menyukai orang-orang yang bertaqwa"(Q.S. At-Taubah: ayat 4).

Pembahasan tentang kepemimpinan, ada juga hadist yang menjelaskan tentang ini yaitu hadist riwayat Bukhari Muslim, yaitu:

"Telah menceritakan Abdullah bin Maslamah dari Malik dari Abdullah ibn Dinar dari Abdullah ibn Umar bahwasanya Rasullah bersabda: Setiap kamu adalah pemimpin dan akan diminta pertanggungjawaban kepemimpinannya, seorang kepala negara adalah pemimpin atas rakyatnya dan akan diminta pertanggungjawaban perihal rahyat yang dipimpinnya. Seorang suami adalah pemimpin bagi keluarganya dan akan diminta pertanggangjawaban perihal keluarga yang dipimpinnya, seorang istri adalaah pemimpin atas rumah tangga suami dan anaknya dan akan diminta pertanggungjawaban atas tugasnya, seorang pembantu adalah bertanggngjawab atas harta tuannya dan akan ditanya dari tanggungjawabnya, dan kamu sekalian adalah pemimpin pemimpin dan akan diminta pertanggungjawaban perihal kepemimpinannya”.(H.R.Bukhari dan Muslim).

Hadist tersebut menjelaskan tentang etika kepemimpinan dalan Islam. Dan etika yang lebih utama adalah tanggungjawab.

\section{Kepemimpinan Non Muslim Menurut}

\section{Hukum Tata Negara Indonesia}

Dasar hukum merupakan norma hukum yang mendasari satu tindakan hukum tertentu sehingga dapat dianggap sah atau dapat dibenarkan oleh hukum tertentu sehingga dapat dibenarkan secara hukum. Ini terdapat dalam UUD 1945. Kepemimpinan Indonesia dilaksanakan berdasarkan dasar negara, merupakan suatu sistem kenegaraan dengan asas "kesatuan dan persatuan Indonesia" yang terdapat pada dasar negara sila ke-3 dan Pasal 1 ayat 1UUD 1945. ${ }^{21}$

Dalam peraturan perundangundangan terdapat Dasar Hukum Tata Negara Indonesia. Prinsip-prinsip negara dalam pembuatan peraturaan perundang-

\footnotetext{
${ }^{21}$ Jimly Asshiddiqie. "Pengantar Ilmu Hukum Tata Negara”.(Jakarta: PT.Grafindo Persada, 2009). hal. 121.
} 
undangan yaitu:22 "berketuhanan yang maha Esa, memperlakukan setiap orang secara bermartabat sebagai sesama manusia, menjamin persatuan dalam kebhinekaan, dibentuk secara demokratis, diterapkan secara transparan dan akuntable, serta ditagakkan melalui proses yang bebas dan tidak memihak, bertujuan menegakkan keadilan bagi seluruh rakyat Indonesia".

Syarat-syarat Kepemimpinan Menurut Hukum Tata Negara Indonesia Perilaku seorang pemimpin sangat mempengaruhi negara itu kedepannya, karena lalainya seorang pemimpin menyebabkan munculnya banyak masalah. Akan tetapi, sebenarnya pemahaman masyarakatlah yang kurang dalam masalah tersebut. Oleh karena itu, pemerintahan akan berjalan maju apabila seseorang yang menjadi pemimpin diakui oleh negara dan UUD 1945.

\begin{tabular}{|c|c|}
\hline Dalam & Hukum Tata \\
\hline & seorang pemimpin \\
\hline
\end{tabular}
kepemimpinan yang ada di Indonesia ada beberaapa jabataan yang fungsinya hampir sama dengan presiden yang membedakan hanya cakupan wilayahnya saja seperti Gubenur, Bupati, Camat hingga yang terkecil cakupan wilayahnya dalam sistem pemarintahan Indonesia.

Indonesia merupakan negara kesatuan yang memiliki banyak ras, suku, dan agama. Sebagai negara hukum Indonesia sangat menjunjung tinggi hak individu setiap warga negara sesuai dalam UUD 1945 pasal 28 D ayat 1 yaitu "setiap orang berhak atas pengakuan, jaminan, perlindungan dan kepastian hukum yang adil serta perlakuan yang sama dihadapaan hukum". Dengan adanya pasal ini yang membuat setiap orang dapat mencalonkan dirinya sebagai seorang pemimpin. ${ }^{23}$ Beberapa syarat calon presiden dan wakil presiden yaitu : "bertakwa kepada Tuhan Yang Maha Indonesia, warga Negara Indonesia sejak kelahirannya dan tidak pernah menerima kewargangaraan lain karena kehendaknya sendiri, tidak pernah menghianati negara,serta tidak pernah melakukan korupsi dan tidak pidana lainnya, mampu secara rohani dan jasmani untuk melaksanakaan tugas dan kewajibaan sebagai presidaen dan wakil presiden,

\footnotetext{
${ }^{23} \mathrm{Abu}$ Daud Busroh. "Intisari Hukum Tatanegara Perbandingan Konstitusi Sembilan Negara".(Jakarta: PT. Bina Aksara, 1987). hal. 33.
} 
AL-IMARAH: Jurnal Pemerintahan dan Politik Islam Vol. 5, No. 2, 2020

bertempat tinggal di Negara Kesatuan Republik Indonesia, sudah melaporkan kekayaannya pada lembaga yang berwenang memeriksa laporan kekayaan penyelanggaraan negara, tidak sedang memiliki tanggungan utang secara perorangan dan secara badan hukum yang menjadi tangungjawabnya yang merugikan keuangan negara, tidak sedang dinyatakan pailit berdasarkan putusan pengadilan, tidak pernah melakukan hal tercela, memiliki visi, misi, dan progam kerja dalam melaksanakan pemerintahan negara Republik Indonesia”. ${ }^{24}$

Syarat kepemimpinan yang ada di Indonesia yang paling utama nomor satu yaitu berketuhanan yang maha esa, yang artinya setiap calon pemimpin harus menganut salah satu kepercayaan, selain itu seorang pemimpin harus memiliki sifat tanggungjawab, bijaksana dan dapat bangsa Indonesia lebih maju.
A. Kepemimpinan Non Muslim Menurut Hukum Tata Negara Indonesia

Dalam UUD 1945 pasal 29 ayat 2 berbunyi "Negara Republik Indonesia menjamin kemerdekaan tiap-tiap penduduk untuk memeluk

\footnotetext{
${ }^{24}$ Undang-Undang Nomor 42 Tahun 2008 tentang pemilu Presiden dan Wakil Presiden, Pasal 5
}

agamanya masing-masing dan untuk beribadat menurut agamanya dan kepercayaannya". Menjelaskan presepsi tentang hukum Islam, hukum Islam berlaku sebagai hukum positif dalam suatu negara, terutama negara muslim atau negara yang warga negaranya kebanyakan muslim seperti Indonesia. ${ }^{25}$ Hal itu tidak mengurangi hak-hak sipil warga negara yang non musim yang terdiri dari "(1) hak untuk dipilih dan memilih sebagai pemimpin, baik langsung maupumn perwakilan (2) hak untuk bermusyawarah/hak untuk ikut berpartisipasi dalam memberikan ide,saran,dan kritik yang membangun kepada penyelangggara yang terpilih, agar tidak membahayakan rakyat (3) hak pengawasan/hak untuk mengontrol daan meluruskan penyimpangan yang dilakukan oleh penyelanggara negara (4) hak untuk memecat pemimpin/penyelenggara dari jabatannya apabila ia tidak dapat menjalankan tugas yang diamanatkan kepadanya dengan baik

\footnotetext{
${ }^{25}$ Ali Imron. "Pertanggungjawaban Hukum, Konsep Hukum Islam dan Relevansinya Dengan Citra Hukum Nasional Indonesia". (Semarang: Walisongo Pres, 2009), hal. 23.
} 
(5) hak untuk mencalonkan diri menjadi penyelanggara negara dan (6) hak untuk menduduki jabatan umum dalam pemerintahan". ${ }^{26}$

Indonesia merupakan negara yang mempunyai bermacam-macam suku, ras, budaya, serta agama. Pembentukan negara yang adil, berdaulat, dan makmur negara Indonesia menerapkan adanya asas keadilan yang mencakup hak, karena asas keadilan merupakan asas yang pnting dalam Islam. ${ }^{27}$ Walaupun Indonesia menerapkan asas tersebut yang mencakup hak, hak bagi para non muslim yang beridentitas warga negara ataupun yang menduduki jabatan tetap diberikan, karena mayoritas warga negara Indonesia beragama Islam.

Syarat yang membolehkan kepemimpinan non muslim, yaitu pada surat At-Taubah ayat 4, yang kesimpulannya terdapat pada konteks Hukum Tata Negara Indonesia yang saat ini adalah "Pembukaan UUD1945, UUD 1945, Lembaga-lembaga dalam sistem ketatanegaraan menurut UUD

\footnotetext{
${ }^{26}$ Mujar Ibnu Syarif. Op. Cit. hal.54
}

${ }^{27}$ Ali Imron.Op.Cit. hal.71
Negara Republik Indonesia tahun 1945 dan Lembaga-lembaga Negara yang memegang kekuasaan menurut UUD 1945”.

Bangsa Indonesia tidak sama dengan Arab saudi sebagai negara yang sudah terlihat sebagai negara Islami, berbeda dengan Indonesia yang identitasnya sebagai negara demokrasi atau negara berpancasila. Pancasila sebagai dasar negara mempunyai peran penting dalam membentuk negara Indonesia, sehingga warga negara minoritas layak untuk menjadi salah satu pemimpin di Indonesia, surat AlMaidah ayat 57 menjelaskan "seorang mukmin dituntut untuk memilih seorang pemimpin dari kalangan yang menjaga sebuah agama agar tidak menjadi bahan ejekan dan permainan". Dari ayat tersebut terlihat jelas bahwa ketika memilih seorang pemimpin maka pilih pemimpin yang menjaga kehormatan agama apapun.Seorang pemimpin sebelum ia menjadi pemimpin ia terlebih dahulu telah melalui proses-proses pemilihan calon pemimpin. 
AL-IMARAH: Jurnal Pemerintahan dan Politik Islam Vol. 5, No. 2, 2020

\begin{abstract}
Pemilihan seorang pemimpin yang yang tingkatannya berada dibawah presiden yang ada di Indonesia, negara Indonesia merupakan negara majemuk dan heterogen, tidak adil jika maayoritas yang menjadi pemimpin adalah orang muslim. Sedangkan negara kita saja negara demokrasi bukan negara Islam seperti Arab Saudi.Kemerdekaan negara kita merupakan hasil dari perjuangan dari pahlawan yang tentunya dari bermacam-macam agama, budaya, bahasa, dan suku.
\end{abstract}

Kepemimpinan non muslim menurut hukum tata negara Indonesia selalu menjadi perdebatan para pakar hukum dan para ahli pemikir politik Islam di Indonesia yang secara tidak langsung menimbulkan pro dan kontra dikalangan para pakar dan masyarakat, jika ditelaah lagi kepemimpinan atau pemimpin dalam konteks Hukum Tata Negara Indonesia dapat dirinci sebagai berikut:

1.) Pembukaan UUD 1945 tidak membedakan adanya perbedaan suku, bangsa, budaya, agama, dll. Maka setiap orang berhak menjadi pemimpin Indonesia selagi pemimpin itu berkewarganegaraan Indonesia dan mampu menjalankan tugas dan kewajiban yang ia tanggung , terkandung dalam UUD 1945 yaitu "Kemudian dari pada itu untuk membentuk pemerintahan Negara Indonesia yang melindungi segenap bangsa Indonesia dan seluruh tumpah darah Indonesia dan untuk memajukan kesejahteraan umum, mencerdaskan kehidupan bangsa dan ikut melaksanakan ketertiban dunia yang berdasarkan kemerdekaan, perdamaian abadi dan keadilan sosial, maka disusunlah kemerdekaan itu dalam suatu susunan negara Republik Indonesia yang berkedaulatan rakyat yang berdasarkan kepada ketuhanan yang Maha Esa, kemanusiaan yang adil dan beradab, persatuan Indonesia, dan kerakyatan yang dipimpin olehhikmat kebijaksanaan dalam permusyawaratan/perwakilan, serta dengan mewujudkan suatu 
keadilan sosial bagi seluruh rakyat Indonesia.

2.) Kandungan dan Implementasi Undang-undang Daasar 1945 yang ditujukan kepada seluruh warga negara Indonesia tanpa membedakan perbedaaan suku, budaya, bangsa, agama, dll.

3.) Warga negara Indonesia jika dilihat dari kandungan Undangundang Dasar 1945 mendapat prioritas utama dalam mengelola Negara Indonesia untuk maju atau bahkan mundur, sebagaimana kandungannya yang berbunyi. "Persatuan Indonesia". Hal itu menunjukkan untuk mencapai suatu negara yang adil dan makmur maka seluruh warga Indonesia harus menjaga persatuan.

Pemimpin non muslim boleh menjadi seorang pemimpin disuatu nagara yang mayoritas penduduknya muslimdalam konteks Hukum Tata Negara Indonesia. Akan tetapi, terlebih dahulu syariasyariat Islam harus terpenuhi diantaranya sebagai berikut: "Sebab darurat yakni jika orang muslim tidak ada lagi yang mampu menjadi seorang pemimpin yang adil, bijaksana, dan tidak mampu membuat perubahan yang lebih baik dan maju, Dengan adanya hal itu tidak menimbulkan fitnah yang dapat memecah belah keutuhan bangsa, Menjalankan kewajiban dan ketetapan undang-undang negara dengan jujur dan adil, Tidak ada niat untuk membuat kedzaliman terhadap umat".

Kepemimpinan yang terdapat pada hukum Islam memang menimbulkan banyak perdebatan dikarenakan Negara Indonesia didiami oleh penduduk yang mayoritas muslim,yang tidak menyetujui adanya kepemimpinan non muslim ialah yang masih berpe pada kebenaran Al-Qur'an yang pemimpinnya harus muslim apabila warga negaranya muslim. Akan tetapi, Indonesia merupakan yang mempunyai dasar hukum Pancasila dan UUD 1945 yang memiliki peraturaan pemberlakukan hak untuk seluruh masyarakat Indonesia.

\section{Penutup}

Sebagian ulama fiqih memang melarang kepemimpinan non muslim dikarenakan hal ini tidak sesuai dengan AlQur'an dan fiqih. Alasannya ditakutkan jika 
AL-IMARAH: Jurnal Pemerintahan dan Politik Islam Vol. 5, No. 2, 2020

yang menjadi pemimpin dari kalangan minoritas pemimpin tersebut akan mengganti hukum-hukum yang telah ditetapkan. Namun ada juga yang memperbolehkan hal itu dengan memperhatikan hukum yang ada dan juga negara Indonesia yang merupakan negara kesatuan dengan beberapa syarat juga yang harus terpenuhi.Hukum Tata Negara Indonesia tidak ada satupunyang mencamtumkan bahwa seorang pemimpin harus Islam, dasar aturan tersebut terdapat pada UUD 1945,UU, dan Pancasila tidak menyertakan hal tersebut.

\section{Pustaka Acuan}

Muhammad Jufri, Ahmad Dahlan. 2018. "Kepemimpinan Non Muslim Di Indonesia Perspektif Hukum Islam", Lisan Al-Hal: Jurnal Pengembangan Pemikiran dan Kebudayaan.

Husnaeni Husnaeni. 2019. “Kajian Hukum Islam terhadap Kepemimpinan Gubernur Non Muslim di Negara Kesatuan Republik Indonesia”, Jurnal Al-Dustar: Journal of politic and islamic law.

Al-Qur'an, Departemen Agama RI AlQur'an dan Terjemah 30 juz.

Al-Mawardi. 2000."Hukum Tata Negara dan Kepemimpinan dalam Takaran
Islam”. Jakarta: Gema Insani Pers.

Muhammad Tahir Azhari. 2012."Beberapa Aspek Hukum Tata Negara, Hukum Pidana, dan Hukum Islam". Jakarta: Prenamedia.

A.Djazuli. 2003. "Fiqih Siyasah Implementasi Kemaslahatan Ummat dalam Rambu-Rambu Syariah Edisi Revisi”. Bandung: Predana Media.

Abul A'la Al-Maudi. 1990.'Hukum dan Konstitusi Politik Islam”. Bandung: Mirzan.

Amanda Rahmat Hidayat. 2013. "Kepemimpinan Non Muslim Menurut Fiqih Siyasah dan Hukum Tata Negara Indonesia". Lampung.

Jimly Asshiddi. 2009. "Pengantar Hukum Tata Negara”. Jakarta: PT. Grafindo.

Abu Daud Busroh. 1987.’Intisari Hukum Tata Negara Perbandingan Konstitusi Sembilan Negara". Jakarta: PT.Bima Aksara.

Undang-Undang Nomor 42 Tahun 2008 tentang "pemilu Presiden dan wakil Presiden", pasal 5.

Ali Imron. 2009."Pertanggungjawaban, Konsep Hukum Islam dan Relevansnya dengan Citra Hukum Nasional Indonesia". Semarang: Walisongo Pers. 
Mujar Ibnu Syarif. 2003. "Hak-Hak Politik

Minoritas Non Muslim dalam

Komunitas Islam”. Bandung: Angkasa

Bandung.

Mudrik Al Farizi. 2016. "Pemimpin Non

Muslim dalam Pandangan Islam”. A1-

Mabsut: Jurnal Studi Islam dan Sosial

10.

Indah Kusuma Dewi, Ali Mashar. 2019.

"Nilai-Nilai Profetik dalam

Kepemimpinan Modern pada

Manajemen Kerja". Jogjakarta: CV.Gre

Publishing.

Muhammad Harfin Zuhdi. 2014. "Konep

Kepemimpinan dalam Perspektif

Islam". Institut Agama Negeri Islam

Mataram. 